\title{
Effect of mineral-energy supplementation on the performance of young bulls from different genetic groups on pasture
}

\section{Efeito da suplementação energética-mineral no desempenho de tourinhos de diferentes grupos genéticos recriados a pasto}

Tiago Pereira Guimarães ${ }^{1 *}$; Ubirajara Oliveira Bilego ${ }^{2}$; Pedro Leonardo de Paula Rezende ${ }^{3}$; Wescley Faccini Augusto4; Wilson Aparecido Marchesin5; Alexey Heronville Gonçalves da Silva ${ }^{5}$; Kíria Karolline Gomes Moreira6; Larissa de Oliveira Ferreira7; João Restle ${ }^{8}$

\section{Highlights}

Energy supplement intake of Brangus young bulls is higher than Nellore and Canchim.

Nelore and Canchim young bulls are more efficient in the use of energy supplement.

The animals performed better with energy supplement than with the mineral supplement.

\begin{abstract}
The aim of this study was to evaluate the performance of young bulls from three genetic groups, $1 / 2$ Brangus $x 1 / 2$ Nellore (BRN), Nellore (NEL) and $1 / 2$ Canchim $x 1 / 2$ Nellore (CAN), reared on pasture and supplemented with mineral (MS) or energy-mineral (MES) supplement. Eighty-one bulls, with a mean age of 12 months and mean body weight of $252 \pm 33 \mathrm{~kg}$ were used. The experiment was conducted in a 3x2 factorial completely randomized design. Each genetic group was subdivided into six experimental plots, three received MS and three received MES. Animals were managed in a rotational stocking system in a Tifton 85 grass pasture. The consumption of MS was similar between the genetic groups with an average of $0.073 \mathrm{~kg} \mathrm{animal}^{-1} \mathrm{day}^{-1}$,

1 Prof. Dr., Animal Science, Instituto Federal Goiano, IFG, Rio Verde, GO, Brazil. E-mail: tiago.guimaraes@ifgoiano.edu.br

2 Dr. Researcher, Cooperativa Agroindustrial dos Produtores Rurais do Sudoeste Goiano, COMIGO, Rio Verde, GO, Brazil. E-mail: birabilego@hotmail.com

3 Dr. President, Agência Goiana de Assistência Técnica, Extensão Rural e Pesquisa Agropecuária, EMATER, Goiânia, GO, Brazil. E-mail: pedrozootec@hotmail.com

${ }^{4}$ Dr., Student of Postgraduate, Program of Tropical Animal Science, Universidade Federal do Tocantins, UFT, Araguaína, TO, Brazil. E-mail: wescleyfaccini@hotmail.com

5 Drs., Manager, COMIGO, Rio Verde, GO, Brazil. E-mail: racaoind@comigo.com.br, alexeyheronville@comigo.com.br

6 Dra, Agência Goiana de Defesa Agropecuária, AGRODEFESA, Rio Verde, GO, Brazil. E-mail: kiriakarolline@hotmail.com

7 M.e, Animal Science, IFG, Rio Verde, GO, Brazil. E-mail: larimedvet@outlook.com

8 Dr. Researcher, Universidade Federal de Goiás, UFG, Goiânia, GO, Brazil. E-mail: jorestle@terra.com.br

* Author for correspondence
\end{abstract}

Received: Nov. 26, 2020 - Approved: Oct. 14, 2021 
whereas the consumption of MES was higher for BRN, $2.10 \mathrm{~kg}^{\text {animal }}{ }^{-1} \mathrm{day}^{-1}$, followed by CAN, with $1.57 \mathrm{~kg}$ animal ${ }^{-1}$ day $^{-1}$, and lower for NEL, with $1.28 \mathrm{~kg}_{\text {animal }}{ }^{-1}$ day $^{-1}$. The average daily weight gain (ADG) was greater for animals that received MES compared to those that were given MS. For animals that received MS, the BRN group had ADG of $0.64 \mathrm{~kg}_{\text {animal }}{ }^{-1}$, while the NEL and CAN groups were similar with a mean of $0.46 \mathrm{~kg}$ animal ${ }^{-1}$. For animals that received MES, the CAN group had higher ADG, $0.97 \mathrm{~kg}$ animal ${ }^{-1}$, while the NEL and BRN groups were similar, with an average of $0.86 \mathrm{~kg}_{\text {animal }}{ }^{-1}$. Blood levels of total protein, albumin, creatinine, glucose and cholesterol did not change depending on the types of supplements used or between genetic groups. Higher serum urea levels were observed in NEL and CAN animals that received MS. Serum aspartate aminotransferase levels were higher in BRN and CAN animals that received MES. Gains in rump height, height at the withers, body length, rump width and chest perimeter were greater in animals that received MES. Mostly, the gains in morphometric measurements were greater for crossbred animals than for the NEL group. The supply of mineral-energy supplement in Tifton 85 grass pasture during the rainy season is recommended only for Nellore and $1 / 2$ Canchim $\times 1 / 2$ Nellore young bulls. Crossbred young bulls show greater gains in morphometric measurements than Nellore young bulls during rearing.

Key words: Body measurements. Crossbreeding. Energy supplement. Metabolic profile.

\section{Resumo}

Objetivou-se com este estudo avaliar o desempenho de tourinhos de três grupos genéticos, $1 / 2$ Brangus x $1 / 2$ Nelore (BRN), Nelore (NEL) e $1 / 2$ Canchim x $1 / 2$ Nelore (CAN), recriados à pasto e suplementados com mineral (SM) ou energético-mineral (SEM). Foram utilizados 81 tourinhos, com idade média de 12 meses e peso corporal médio de $252 \pm 33 \mathrm{~kg}$. O experimento foi conduzido em delineamento inteiramente ao acaso em esquema fatorial $3 \times 2$. Cada grupo genético foi subdividido em seis parcelas experimentais, em que três delas receberam SM e três receberam SEM. Os animais foram manejados em sistema de lotação rotacionada em pasto de capim Tifton 85. O consumo de SM foi semelhante entre os grupos genéticos com média de $0,073 \mathrm{~kg}_{\text {animal }}{ }^{-1} \mathrm{dia}^{-1}$, já o consumo de SEM foi maior para o BRN com 2,10 kg animal-1 dia $^{-1}$, seguido pelo CAN com 1,57 kg animal ${ }^{-1} \mathrm{dia}^{-1}$ e menor para o NEL com 1,28 kg animal-1 $\mathrm{dia}^{-1}$. O ganho de peso médio diário (GMD) foi maior para os animais que receberam SEM em relação aos que receberam SM. Para os animais que receberam SM, o grupo BRN apresentou GMD de 0,64 $\mathrm{kg}^{\text {animal-1}}{ }^{-1}$, enquanto os grupos NEL e CAN foram semelhantes com média de $0,46 \mathrm{~kg}_{\text {animal }}^{-1}$. Para os animais que receberam SEM o grupo CAN apresentou maior GMD com 0,97 kg animal-1, enquanto os grupos NEL e BRN foram semelhantes com média de $0,86 \mathrm{~kg}_{\text {animal }}{ }^{-1}$. Os níveis sanguíneos de proteína total, albumina, creatinina, glicose e colesterol não foram alterados em função dos tipos de suplementos utilizados ou entre os grupos genéticos. Maiores níveis séricos de ureia foram observados nos animais NEL e CAN que receberam SM. Os níveis séricos de aspartato aminotransferase foram maiores em animais BRN e CAN que receberam SEM. Os ganhos de altura de garupa, altura de cernelha, comprimento, largura de garupa, perímetro torácico e largura de peito foram maiores em animais que receberam SEM. Em sua maioria, os ganhos de medidas morfométricas foram maiores para os animais mestiços do que para o NEL. O fornecimento de suplemento energético-mineral em pasto de capim Tifton 85 durante o período das águas é recomendado apenas para tourinhos Nelore e $1 / 2$ Canchim $\times 1 / 2$ Nelore. Tourinhos mestiços apresentam maiores ganhos em medidas morfométricas que tourinhos Nelore durante a recria.

Palavras-chave: Cruzamentos. Medidas corporais. Perfil metabólico. Suplemento energético. 


\section{Introduction}

Beef cattle ranching in Brazil is based on tropical pastures, the most practical and economical way for livestock production. In general, tropical pastures may not meet the nutritional requirements of precocious animals so that they can express the genetic potential for maximum weight gain, even in the rainy season, favorable period for quality forage. Supplementation in the rainy season aims to provide potentially digestible nutrients and reduce dietary deficiencies of forages, allowing the animal to increase the intake of digestible nutrients, improving productivity and feed efficiency to reach carcass weight and composition for slaughter at a younger age, which would not be achieved only with the intake of forage and mineral supplementation (Dias et al., 2015).

In Brazil, few positive responses of animalperformancetoenergysupplementation have been reported with Tifton 85 grass, and studies with positive results are associated with rotational grazing management and high levels of nitrogen fertilization of the pasture (Detmann, Paulino, Valadares, \& Huhtanen, 2014). Energy supplementation in the rainy season during rearing increased the weight gain of animals on Urochloa brizantha pasture (Rezende et al., 2011) and, consequently, increased weight at the end of rearing and beginning of finishing. This strategy can result in less time to reach slaughter weight (Lima et al., 2012; Freitas et al., 2014) and reduce costs in finishing.

In the rainy season, there is a range of responses regarding animal performance with the use of supplementation, as in this period the feasibility of this technique depends on the balance between the supplement characteristics and nutrients available in the pasture, controlled by grazing management strategies, which can define the level of performance of animals (Costa et al., 2019; Ziemniczak et al., 2020).

Crossing beef cattle breeds are used to increase the efficiency of meat production, both by providing the complementarity between breeds and by the manifestation of heterosis. According to F. S. Moreira et al. (2015), the use of crosses between zebu and taurine in the Brazilian cerrado region has great potential to produce animals with adequate growth on pasture and fast finishing in feedlot, with high meat quality. Crossbred cattle are commonly farmed in Brazil due to its better adaptability to the tropical environment (Valente et al., 2012).

In this context, this study hypothesized that crossbred cattle receiving energy-mineral supplementation have better performance than Nellore cattle receiving mineral supplementation on Tifton 85 grass pasture. Given the above, the objective was to evaluate the performance of young bulls from different genetic groups receiving energy-mineral supplementation on pasture during the rainy season.

\section{Material and Methods}

The research was approved by the Ethics Committee of the Federal University of Goiás, according to protocol 088/14, and all procedures involving the animals were conducted in accordance with the ethical guideline adopted by the Conselho Nacional de Controle de Experimentação Animal [CONCEA] (2013). The experiment was conducted from January to May, totaling 
112 days, in the Livestock Sector of the Institute of Science and Technology of the Cooperativa Agroindustrial dos Produtores Rurais do Sudoeste Goiano (COMIGO ${ }^{\circledR}$ ) in the municipality of Rio Verde, state of Goiás, at $846 \mathrm{~m}$ altitude, latitude 17046'13.50" South and longitude $51^{\circ} 02^{\prime} 08.23^{\prime \prime}$ West.

Eighty-one young bulls with an initial mean age of $12 \pm 1$ months and mean body weight of $252 \pm 33 \mathrm{~kg}$ were assigned to six treatments of a $2 \times 3$ factorial completely randomized design of two supplements and three genetic groups. The supplements used were: mineral supplement(MS) Cria $61^{\circledR}(\mathrm{F} 2)$ and mineral-energy supplement (MES) Engorda Águas $^{\circledR}$ (F8), both commercial products from $\mathrm{COMIGO}^{\circledR}$. The genetic groups were Nellore (NEL, with 27 animals), $1 / 2$ Canchim $\times 1 / 2$ Nellore (CAN, with 27 animals) and $1 / 2$ Brangus $\times 1 / 2$ Nellore (BRN, with 27 animals). Each genetic group was subdivided into six experimental plots (three plots with five animals and three plots with four animals), in which three of them received mineral supplement and three received mineral-energy supplement. Thus, each treatment consisted of three repetitions totaling 18 experimental units. Assurance levels of the supplements used are listed in Table 1.

Animals were managed in a rotational stocking system, in a totalarea of 6.88 hectares, divided into 12 paddocks of homogeneous sizes, approximately 0.57 ha, consisting of Cynodon spp. cv. Tifton 85. Paddocks were separated into three modules; each genetic group was maintained in a separate module regardless of the type of supplementation, containing four paddocks each, with an occupation period of 3 to 4 days and rest of 14 to 16 days for each paddock. Every 28 days the groups were also rotated between modules.

For supplementation, each genetic group was taken to the management pen located next to the pasture area every day and, subsequently, separated into two groups according to the type of supplement they received (mineral or energy mineral supplement), by identifying the ear tag. Subsequently, they were confined in collective pens to consume the supplements, in which a feeder with 1.5 linear meters was available for each animal and a drinker with automatic level control. Animals remained in this place from $10 \mathrm{~h} 00$ to $14 \mathrm{~h} 00$ to consume the supplements and, later, were returned to the respective grazing modules. Supplements were ad libitum offered to the animals, controlling leftovers between 5 and $10 \%$ total offered. The average daily intake of the supplement was measured by the difference between the amount offered and the leftovers, by the average of each experimental unit. 
Table 1

Assurance levels of the mineral supplement (MS) and the mineral-energy supplement (MES)

\begin{tabular}{|ccc|}
\hline Supplement & MS & MES \\
\hline Ground corn, $\mathrm{g} \mathrm{kg}^{-1}$ & - & 781.8 \\
\hline Calcium, $\mathrm{kg}^{-1}$ & 123.0 & 29.0 \\
\hline Phosphorus, $\mathrm{g} \mathrm{kg}^{-1}$ & 61.0 & 9.0 \\
\hline Sodium, $\mathrm{kg}^{-1}$ & 150.0 & 22.0 \\
\hline Magnesium, $\mathrm{g} \mathrm{kg}^{-1}$ & 5.0 & 1.8 \\
\hline Sulfur, $\mathrm{g} \mathrm{kg}^{-1}$ & 9.0 & 5.0 \\
\hline Copper, $\mathrm{mg} \mathrm{kg}^{-1}$ & $1,630.0$ & 120.0 \\
\hline Manganese, $\mathrm{mg} \mathrm{kg}^{-1}$ & $1,000.0$ & 64.0 \\
\hline Zinc, $\mathrm{mg} \mathrm{kg}^{-1}$ & $5,783.0$ & 360.0 \\
\hline Cobalt, $\mathrm{mg} \mathrm{kg}^{-1}$ & 160.0 & 10.0 \\
\hline lodine, $\mathrm{mg} \mathrm{kg}^{-1}$ & 165.0 & 10.0 \\
\hline Selenium, $\mathrm{mg} \mathrm{kg}^{-1}$ & 25.0 & 1.0 \\
\hline Fluorine, $\mathrm{mg} \mathrm{kg}^{-1}$ & 0.1 & 0.1 \\
\hline Vitamin $\mathrm{A}, \mathrm{IU}^{-1}$ & - & $60,000.0$ \\
\hline Vitamin $\mathrm{D}, \mathrm{IU}$ & - & $120,000.0$ \\
\hline Vitamin $\mathrm{E}, \mathrm{IU}^{-1}$ & - & 4.0 \\
\hline Crude Protein, $\mathrm{g} \mathrm{kg}^{-1}$ & - & 660.0 \\
\hline
\end{tabular}

Forage was sampled using a square iron frame of $0.25 \mathrm{~m}^{2}$, in the grazing layer at $10 \mathrm{~cm}$ from the ground, randomly thrown in two places of each paddock, obtained at the beginning, in the middle and at the end of each 28-day cycle. The green material was weighed, and a sub-sample was sent to the laboratory for dry matter calculation and chemical analysis. Concentrations were analyzed based on dry matter (DM), including crude protein, ether extract (EE), mineral matter (MM), calcium and phosphorus, according to the methodologies of the Association of Official Analytical Chemists [AOAC] (1990); and neutral detergent fiber (NDF) and acid detergent fiber (ADF), according to Van Soest, Robertson and Lewis (1991); and the metabolizable energy (ME),
Mcal $\mathrm{kg}^{-1} \mathrm{DM}$ was estimated according to the National Academies of Sciences, Engineering, and Medicine [NASEM] (2016).

Forage mass (kg DM ha-1) per grazing cycle was estimated from the collection of samples at the beginning and end of each 14day cycle, that is, collected at the entrance of the animals in each paddock of the grazing modules. In this way, the average of all cycles of the experimental period was calculated. Forage mass was calculated by the following equation: $F M=M A \times 10,000$, where: $F M=$ forage mass; $M A=$ mean value of the amount of dry matter per $\mathrm{m}^{2}$ in the sampled points (kg DM $\mathrm{m}^{-2}$ ); and $10,000=$ equivalent to an area of one hectare in $\mathrm{m}^{2}$. Forage supply (kg DM per $100 \mathrm{~kg} \mathrm{BW} \mathrm{d}^{-1}$ ) was estimated by the following 
equation: $F S=(F M D / A A L) \times 100$, where: $F S=$ forage supply, $F M D=$ forage mass available daily during the paddock occupation period $\left(\mathrm{kg} \mathrm{DM} \mathrm{ha}^{-1} \mathrm{~d}^{-1}\right)$; and $\mathrm{AAL}=$ average animal load during the paddock occupation period (kg of BW ha-1). Forage canopy height was measured at the beginning and end of each 28-day cycle, at 10 random points per paddock, using a graduated ruler and a transparent plastic sheet, which was positioned on top of the sward, and obtained the height in the middle of the sheet, then the average of the 10 points was made.

As the genetic groups remained in separate grazing modules, the chemical composition and forage supply in the paddocks in which the animals were placed and when they changed grazing module were evaluated. The stocking rate $\left(\mathrm{AU} \mathrm{ha}^{-1}\right)$ was calculated by the sum of the mean body weight (MBW) of each genetic group, divided by one animal unit $(450 \mathrm{~kg})$. As the supplements were ad libitum supplied, there was no regulation of stocking rate, however, the animals were rotated for fallow and better regrowth of the grass.

Animals were weighed on a digital scale (Toledo, model MGR $3000^{\circledR}$ ) on days 1 , $28,56,84$ and 112 to monitor weight gain. To obtain the total weight gain (TWG), the initial weight was used and at 112 days, preceded by a 12-hour fasting of solids and liquids. The ADG was obtained by dividing the TWG by the 112 experimental days.

Body measurements were taken at the beginning and at the end of the rearing phase on pasture, using a measuring tape and a hypometric cane. Height at the withers $(\mathrm{HW})$, chest perimeter $(\mathrm{CP})$, body length $(\mathrm{BL})$, rump height $(\mathrm{RH})$ and rump width $(\mathrm{RW})$ were measured as described by Rezende et al. (2011). The gains of these morphometric measurements were obtained by the difference between the final and initial measurements.

On the first and last day of the experimental period, blood samples were taken from three animals per experimental unit, prior to supplementation in the morning, by puncturing the coccygeal vein and/ or artery with Vacutainer ${ }^{\circledR}$ tubes and $12 \times 8$ hypodermic needles. To determine the glucose concentration, blood samples were collected in tubes containing sodium fluoride, and for the determination of other biochemical parameters, samples were collected in tubes without anticoagulant. After collection, tubes were stored in coolers containing ice. Subsequently, samples were centrifuged at $2,000 \mathrm{G}$ for 15 minutes to separate plasma (glucose) and serum (other metabolites), which were placed in Eppendorf ${ }^{\circledR}$ microtubes, with a volume of $1.5 \mathrm{~mL}$, identified and frozen at $-20^{\circ} \mathrm{C}$. These samples were sent to the laboratory for biochemical analyses using commercial kits (Labtest Diagnostic $\mathrm{SA}^{\circledR}$ ) to determine the concentrations of total protein (REF. 99), albumin (REF. 19), creatinine (REF. 35), urea (REF. 27), glucose (REF. 134), total cholesterol (REF. 13) and aspartate aminotrasferase (REF. 109). Readings were taken in a Bioplus ${ }^{\circledR}$ spectrophotometer, Bio-2000 IL-A.

Data were tested by analysis of variance in $2 \times 3$ factorial scheme, obeying the assumptions of parametric analysis, such as normality (Shapiro-Wilk) and homoscedasticity (F-Test). Two models were tested, one using the initial weight as a covariate and the other without the initial weight. Models were submitted to the likelihood ratio test, and as there was no difference, the simplest model was chosen, without using the initial weight as a covariate. Mean values were compared by 
Tukey's test at the 5\% probability level, using the package "easyanova" (Arnhold, 2013) of the $\mathrm{R}$ software, according to the statistical model: $Y i j k=\mu+R i+S j+R S i j+e i j k$, where: $Y i j k$ = observation referring to animal $\mathrm{k}$ in genetic group $\mathrm{i}$ and supplement $\mathrm{j} ; \mu=$ overall mean; $\mathrm{Ri}=$ effect of genetic group $i ; \mathrm{Sj}=$ effect of supplement j; RSij = effect of genetic group $\mathrm{x}$ supplement interaction; and eijk = random error associated with each observation.

\section{Results and Discussion}

The canopy height at the entrance of animals into the paddocks was similar between the genetic groups, with an average of $24.7 \mathrm{~cm}$ (Table 2). Forage mass and forage supply did not differ ( $P>0.05$ ) between modules of genetic groups, indicating that forage remained uniformly distributed in all treatments. The average forage supply was

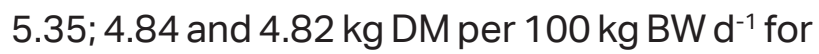
BRN, NEL and CAN, respectively. Considering that the estimated dry matter intake for Nellore cattle with characteristics similar to those used in this study is $2.5 \% \mathrm{BW}$, according to the NASEM (2016), and that the average weight of the animals during rearing was $292.8 \mathrm{~kg} \mathrm{BW}$, the average intake per animal expected would be $7.32 \mathrm{~kg} \mathrm{DM}$ day $^{-1}$ or $2.5 \mathrm{~kg}$ DM per $100 \mathrm{~kg}$ BW, therefore, the average forage supply for the three genetic groups were higher than the demand for dry matter intake, not being a limiting factor for animal performance.

\section{Table 2}

Mean values of canopy height, forage mass, forage supply and stocking rate per cycle, according to each genetic group kept in different modules of Tifton 85 grass pasture

\begin{tabular}{lccccc} 
Variables & \multicolumn{3}{c}{ Grazing Modules } & \multirow{2}{*}{ SEM } & \multirow{2}{*}{ P-value } \\
\cline { 2 - 4 } Total area of modules (ha) & BRN & NEL & CAN & & - \\
Canopy height at entry (cm) & 2.43 & 2.38 & 2.27 & - & - \\
Average forage mass (kg DM ha-1) & 24.42 & 25.65 & 24.10 & 1.43 & 0.725 \\
Forage supply (kg DM 100 kg BW-1 $\mathrm{d}^{-1}$ ) & 4,431 & 4,368 & 4,092 & 241.87 & 0.893 \\
Stocking (AU ha-1) & 5.36 & 4.84 & 4.82 & 0.72 & 0.845 \\
\hline
\end{tabular}

BRN $=1 / 2$ Brangus $\times 1 / 2$ Nellore; NEL = Nellore; CAN = $1 / 2$ Canchim $\times 1 / 2$ Nellore; SEM = standard error of the mean.

There was no difference $(P>0.05)$ in the chemical composition of the forage between the grazing modules, presenting, on average, $98 \mathrm{~g} \mathrm{~kg}^{-1}$ crude protein; $729 \mathrm{~g} \mathrm{~kg}^{-1} \mathrm{NDF} ; 417$ $\mathrm{g} \mathrm{kg}^{-1}$ ADF; $3 \mathrm{~g} \mathrm{~kg}^{-1} \mathrm{Ca} ; 6 \mathrm{~g} \mathrm{~kg}^{-1} \mathrm{P}$ and 2.10 Mcal kg-1 ME, on a DM basis (Table 3 ). Results reported by Paris et al. (2013) demonstrated that pastures of the genus Cynodon (Estrela africana, Coastcross and Tifton 85), when well managed with adequate forage allowance, have high protein content, which allows greater potential for weight gain with the use of energy supplement. Higher crude protein values for Tifton 85 grass compared to the present study were reported by Martini et al. (2020), however, samples were collected by hand plucking 
between the months of December to April. The lower values of the present study may be related to the lower rainfall at the end of the study period, which was in May, making the forage more fibrous and with greater reduction in the crude protein content.

The initial weight of the CAN group was lower than the BRN and NEL groups, although the age in months was similar for the three genetic groups (Table 4). There was an interaction $(P=0.001)$ between genetic group and type of supplement for average daily supplement intake expressed in $\mathrm{kg}_{\text {animal- }}{ }^{-1}$ and $\mathrm{kg}$ per $100 \mathrm{~kg} \mathrm{BW}$. The average daily intake of MS was similar between the genetic groups with an average of $0.073 \mathrm{~kg} \mathrm{day}{ }^{-1}$, indicating that the animals responded similarly to the sodium chloride consumption limitation aid. As for the animals that received MES, there was a difference $(P=0.001)$ in consumption between the genetic groups in both $\mathrm{kg}$ animal and $\mathrm{kg}$ per $100 \mathrm{~kg} \mathrm{BW.} \mathrm{BRN} \mathrm{had} \mathrm{the} \mathrm{highest}$ consumption with an average of $2.10 \mathrm{~kg} \mathrm{day}^{-1}$, followed by CAN with $1.57 \mathrm{~kg} \mathrm{day}^{-1}$ and by NEL with $1.28 \mathrm{~kg} \mathrm{day}^{-1}$, with consumption in $\mathrm{kg}$ per $100 \mathrm{~kg} \mathrm{BW}$ crude protein exhibiting a similar behavior. The higher consumption of BRN may be related to its higher nutritional demand for energy and higher fat deposition in relation to NEL, as reported by Putrino et al. (2006), which compared the two genetic groups.

Table 3

Mean chemical composition in DM of Tifton 85 grass in the paddocks of genetic groups

\begin{tabular}{lccccc}
\hline \multirow{2}{*}{ Variables } & \multicolumn{3}{c}{ Grazing Modules } & \multirow{2}{*}{ SEM } & P-value \\
\cline { 2 - 4 } & BRN & NEL & CAN & & \\
Dry matter, g kg-1 natural matter & 269.0 & 287.2 & 272.4 & 43.3 & 0.951 \\
Crude protein, $\mathrm{g} \mathrm{kg}^{-1} \mathrm{DM}$ & 90.4 & 106.7 & 96.1 & 9.1 & 0.560 \\
Ether extract, $\mathrm{g} \mathrm{kg}^{-1} \mathrm{DM}$ & 8.7 & 9.1 & 12.1 & 2.6 & 0.305 \\
Mineral matter, $\mathrm{g} \mathrm{kg}^{-1} \mathrm{DM}$ & 58.6 & 70.8 & 62.0 & 5.6 & 0.350 \\
Neutral detergent fiber, g kg-1 DM & 745.4 & 689.7 & 751.3 & 42.0 & 0.537 \\
Acid detergent fiber, g kg-1 DM & 424.9 & 391.3 & 433.9 & 29.3 & 0.571 \\
Calcium, g kg-1 DM & 3.3 & 3.3 & 3.3 & 0.7 & 0.999 \\
Phosphorus, g kg-1 DM & 5.8 & 5.1 & 5.7 & 0.8 & 0.848
\end{tabular}

BRN $=1 / 2$ Brangus $\times 1 \frac{1}{2}$ Nellore; NEL = Nellore; CAN = $1 \frac{1}{2}$ Canchim $\times 1 \frac{1}{2}$ Nellore; SEM = standard error the mean. Metabolizable energy, Mcal kg-1 DM = estimated by the NASEM (2016). 
Table 4

Mean and standard error of the mean of performance variables of young bulls from three genetic groups, receiving different supplements, on a Tifton 85 grass pasture during the rainy season

\begin{tabular}{|c|c|c|c|c|c|c|c|c|}
\hline \multirow{2}{*}{ Variables } & \multirow{2}{*}{ S } & \multicolumn{3}{|c|}{ GG } & \multirow{2}{*}{ Mean } & \multicolumn{3}{|c|}{ P-value } \\
\hline & & BRN & NEL & CAN & & GG & S & GGxS \\
\hline \multirow{3}{*}{ IBW, kg } & MS & $261.41 \pm 7.14$ & $256.12 \pm 5.92$ & $237.62 \pm 9.92$ & $251.60 \pm 2.40$ & 0.001 & 0.578 & 0.343 \\
\hline & MES & $269.42 \pm 8.71$ & $258.44 \pm 6.72$ & $232.91 \pm 9.94$ & $253.61 \pm 2.40$ & & & \\
\hline & Mean & $265.39^{A} \pm 2.94$ & $257.26^{A} \pm 2.94$ & $235.29^{\mathrm{B}} \pm 2.94$ & & & & \\
\hline \multirow{3}{*}{$\begin{array}{l}\text { SC, } \mathrm{kg} \\
\text { day }^{-1}\end{array}$} & MS & $0.05^{\mathrm{Ab}} \pm 0.01$ & $0.11^{\mathrm{Ab}} \pm 0.01$ & $0.06^{\mathrm{Ab}} \pm 0.01$ & $0.07 \pm 0.01$ & 0.001 & 0.001 & 0.001 \\
\hline & MES & $2.10^{\mathrm{Aa}} \pm 0.01$ & $1.28^{\mathrm{Ca}} \pm 0.10$ & $1.57^{\mathrm{Ba}} \pm 0.01$ & $1.65 \pm 0.01$ & & & \\
\hline & Mean & $1.08 \pm 0.03$ & $0.70 \pm 0.03$ & $0.81 \pm 0.03$ & & & & \\
\hline \multirow{3}{*}{$\begin{array}{l}\text { SC \% BW, } \\
\mathrm{kg} \mathrm{day}^{-1}\end{array}$} & MS & $0.02^{\mathrm{Ab}} \pm 0.01$ & $0.04^{\mathrm{Ab}} \pm 0.01$ & $0.02^{\mathrm{Ab}} \pm 0.01$ & $0.02 \pm 0.01$ & $<0.001$ & $<0.001$ & $<0.001$ \\
\hline & MES & $0.66^{\mathrm{Aa}} \pm 0.01$ & $0.42^{\mathrm{Ca}} \pm 0.01$ & $0.55^{\mathrm{Ba}} \pm 0.01$ & $0.54 \pm 0.01$ & & & \\
\hline & Mean & $0.34 \pm 0.01$ & $0.22 \pm 0.01$ & $0.28 \pm 0.01$ & & & & \\
\hline \multirow{3}{*}{ ADG, kg } & MS & $0.64^{\mathrm{Ab}} \pm 0.10$ & $0.44^{\mathrm{Bb}} \pm 0.01$ & $0.48^{\mathrm{Bb}} \pm 0.01$ & $0.52 \pm 0.02$ & 0.011 & 0.001 & 0.003 \\
\hline & MES & $0.87^{\mathrm{Ba}} \pm 0.01$ & $0.85^{\mathrm{Ba}} \pm 0.10$ & $0.97^{\mathrm{Aa}} \pm 0.20$ & $0.90 \pm 0.02$ & & & \\
\hline & Mean & $0.76 \pm 0.02$ & $0.65 \pm 0.02$ & $0.73 \pm 0.02$ & & & & \\
\hline \multirow{3}{*}{ TWG, kg } & MS & $71.82^{\mathrm{Ab}} \pm 3.10$ & $49.06^{\mathrm{Bb}} \pm 3.41$ & $53.41^{\mathrm{Bb}} \pm 3.71$ & $58.10 \pm 1.97$ & 0.015 & 0.001 & 0.004 \\
\hline & MES & $97.67^{\mathrm{Ba}} \pm 3.10$ & $95.83^{\mathrm{Ba}} \pm 6.72$ & $108.82^{\mathrm{Aa}} \pm 4.54$ & $100.71 \pm 1.97$ & & & \\
\hline & Mean & $84.74 \pm 2.41$ & $72.44 \pm 2.41$ & $81.11 \pm 2.41$ & & & & \\
\hline \multirow{3}{*}{ FBW, kg } & MS & $333.21 \pm 8.01$ & $305.13 \pm 6.92$ & $296.31 \pm 11.01$ & $311.52^{b} \pm 3.83$ & 0.001 & 0.001 & 0.507 \\
\hline & MES & $367.12 \pm 9.72$ & $354.32 \pm 10.32$ & $341.82 \pm 12.03$ & $354.42^{\mathrm{a}} \pm 3.83$ & & & \\
\hline & Mean & $350.13^{\mathrm{A}} \pm 4.68$ & $329.71^{\mathrm{B}} \pm 4.68$ & $319.03^{B} \pm 4.68$ & & & & \\
\hline
\end{tabular}

BRN $=1 / 2$ Brangus $\times 1 / 2$ Nellore; NEL = Nellore; CAN = $1 / 2$ Canchim $\times 1 / 2$ Nellore; MS= Mineral supplement and MES = Energy mineral supplement. Different uppercase letters, in the same row, and different lowercase letters, in the same column, are significantly different by Tukey's test at the $5 \%$ probability level. GG = genetic group; $\mathrm{S}=$ supplement; IBW = initial body weight; SC = supplement consumption; BW = body weight; $A D G$ = average daily gain; TWG = total weight gain; FBW = final body weight.

There was interaction $(P=0.003)$ between type of supplement and genetic group regarding average daily gain (ADG) and total weight gain (TWG) (Table 4). For animals treated with MS, the BRN group showed the best ADG $\left(0.64 \mathrm{~kg} \mathrm{day}^{-1}\right)$, followed by CAN $\left(0.48 \mathrm{~kg} \mathrm{day}^{-1}\right)$ and NEL $\left(0.44 \mathrm{~kg} \mathrm{day}^{-1}\right)$, in which the last two groups did not differ from each other. For animals that consumed MES, CAN had higher ADG (0.97 $\left.\mathrm{kg}^{\text {day }}{ }^{-1}\right)$ than NEL (0.85 $\left.\mathrm{kg} \mathrm{day}^{-1}\right)$ and BRN $\left(0.87 \mathrm{~kg} \mathrm{day}^{-1}\right)$ even with consumption of MES of $0.53 \mathrm{~kg}^{\text {day }}{ }^{-1}$ less than BRN.
ADG and TWG of animals receiving MES were higher than in animals that received MS, with a difference of $0.23 \mathrm{~kg} \mathrm{day}^{-1}$ for BRN, $0.41 \mathrm{~kg} \mathrm{day}^{-1}$ for NEL and $0.49 \mathrm{~kg} \mathrm{day}^{-1}$ for CAN. The lower performance of animals that received $\mathrm{MS}$ can be explained by the lower energy content in the diet to maintain rumen synchronization, and there may have been excess protein sources, which led to greater absorption of rumen ammonia and increased serum levels of blood urea (González, 2009; Kozloski, 2011). Animals that consumed MES had higher energy input, where, taking into 
account the TDN content of the supplement (Table 1), the consumption of $1.44 ; 1.08$ and $0.88 \mathrm{~kg}$ day $^{-1}$ TDN for the BRN, CAN and NEL groups, respectively. This allowed for better synchrony between energy and degradable protein in the rumen, which is critical for greater microbial protein synthesis and consequently higher animal performance. Furthermore, according to Barbero et al. (2015), under wellmanaged tropical pasture conditions, energy supplementation can be used for nutrient balance and efficient use.

What may have contributed to the good result of BRN with MS is the fact that they were reared in the same paddock as the BRN group that received MES, and these had a high consumption of MES, which may have led to lower forage intake. In this condition, the BRN group from the MS treatment had greater opportunity to select the most nutritious parts of the plant for grazing, resulting in a greater weight gain than the NEL and CAN. Similarly, Lima et al. (2012) found that the supplementation strategies evaluated resulted in similar performance when used during the rainy-dry transition period, under conditions of high forage supply, allowed a great selective capacity of animals for more nutritious parts of the plants, that is, the leaves, thus decreasing the effect of increasing levels of supplementation on animal performance. Roth et al. (2019) also reported that in the rainy season, performance was not influenced by the level of supplementation, due to the high quality of the forage combined with less need for selection during grazing, due to the lower stocking rate.

Regarding genetic groups, the present study corroborated Cruz et al. (2009), who observed gains of $0.48 ; 0.63 ; 0.68$ and 0.50 $\mathrm{kg} \mathrm{day}^{-1}$ for Nellore, $1 / 2$ Canchim x $1 / 2$ Nellore,
$1 / 2$ Angus $\times 1 / 2$ Nellore and $1 / 2$ Simmental $\times 1 / 2$ Nellore animals, respectively, which received mineral mixture in pastures of Cynodon dactylon, cv. Coastcross. The authors reported that $1 / 2$ Canchim $\times 1 / 2$ Nellore and $1 / 2$ Angus $\times 1 / 2$ Nellore animals that received mineral mixture had higher ADG compared to the other groups, and concluded that it can be attributed to the greater potential for weight gain of the animals, related to the greatest heterosis retained in the two crosses. Also, according to the same authors, the Simmental $\times$ Nellore animals, which also have heterosis for weight gain, but did not obtain the same result, probably because they have different nutritional requirements from the other genetic groups, because they have a larger adult size than the other genetic groups.

The better performance of the CAN group consuming MES compared to BRN and NEL can be related to the genes of the Charolais breed, known for its large adult size and high weight gain (F. N. Vaz et al., 2002). The ADG of the NEL group was similar to the $B R N$, thus, they were more efficient, since the consumption was $0.82 \mathrm{~kg} \mathrm{day}^{-1}$ lower than the BRN group. The lower ADG of BRN in relation to the high intake of MES may be related to the effect of replacing forage with the supplement. With the possible reduction in forage intake, there may also have been a lower intake of crude protein from the forage, causing an imbalance in the amount of crude protein and energy for microbial growth in the rumen, since the supplement used was based on corn and minerals. On an unbalanced protein diet, with low availability of nitrogen compounds and high NDF content, the supply of degradable protein in the rumen becomes limiting for the microbial growth of fiber-degrading bacteria, impairing cell wall digestion with a consequent reduction of food intake (Detmann et al., 2014). 
As the weight of animals within each genetic group was balanced at the onset of the experiment (Table 4), the initial morphometric measurements did not differ $(P>0.05)$ between the two supplements used (Table 5).

\section{Table 5}

Mean and standard error of the mean of body measurement variables of young bulls from three genetic groups supplemented in the rainy season

\begin{tabular}{|c|c|c|c|c|c|c|c|c|}
\hline \multirow{2}{*}{$\begin{array}{l}\text { Variables } \\
\text { (cm) }\end{array}$} & \multirow{2}{*}{ S } & \multicolumn{3}{|c|}{ GG } & \multirow{2}{*}{ Mean } & \multicolumn{3}{|c|}{ P-value } \\
\hline & & BRN & NEL & CAN & & GG & $\mathrm{S}$ & GGxS \\
\hline \multirow{3}{*}{ Initial HW } & MS & $121.87 \pm 0.81$ & $129.21 \pm 1.11$ & $124.21 \pm 1.42$ & $125.17 \pm 0.60$ & $<0.001$ & 0.332 & 0.643 \\
\hline & MES & $120.04 \pm 1.21$ & $129.46 \pm 0.93$ & $123.15 \pm 1.25$ & $124.22 \pm 0.60$ & & & \\
\hline & Mean & $120.91^{c} \pm 0.77$ & $129.34^{\mathrm{A}} \pm 0.74$ & $123.68^{\mathrm{B}} \pm 0.74$ & & & & \\
\hline \multirow{3}{*}{ HW gain } & MS & $4.53 \pm 0.62$ & $4.61 \pm 0.64$ & $3.00 \pm 0.42$ & $4.14^{b} \pm 0.39$ & 0.019 & $<0.001$ & 0.121 \\
\hline & MES & $8.41 \pm 1.02$ & $5.62 \pm 0.43$ & $6.00 \pm 0.61$ & $6.71^{a} \pm 0.41$ & & & \\
\hline & Mean & $6.41^{A} \pm 0.50$ & $5.12^{\mathrm{AB}} \pm 0.48$ & $4.52^{\mathrm{B}} \pm 0.48$ & & & & \\
\hline \multirow{3}{*}{ Initial CP } & MS & $152.61 \pm 1.45$ & $151.07 \pm 1.48$ & $147.57 \pm 2.45$ & $150.42 \pm 0.91$ & 0.018 & 0.828 & 0.468 \\
\hline & MES & $150.16 \pm 1.51$ & $152.62 \pm 1.24$ & $147.62 \pm 1.91$ & $150.13 \pm 0.95$ & & & \\
\hline & Mean & $151.49^{\mathrm{A}} \pm 1.17$ & $151.84^{A} \pm 1.13$ & $147.69^{B} \pm 1.13$ & & & & \\
\hline \multirow{3}{*}{$\mathrm{CP}$ gain } & MS & $12.84 \pm 1.34$ & $7.17 \pm 1.14$ & $10.00 \pm 1.45$ & $10.00^{b} \pm 0.61$ & $<0.001$ & $<0.001$ & 0.895 \\
\hline & MES & $19.83 \pm 1.38$ & $14.79 \pm 1.48$ & $18.00 \pm 0.84$ & $17.51^{a} \pm 0.63$ & & & \\
\hline & Mean & $16.34^{A} \pm 0.78$ & $10.98^{\mathrm{B}} \pm 0.75$ & $14.00^{A} \pm 0.75$ & & & & \\
\hline \multirow{3}{*}{ Initial BL } & MS & $110.31 \pm 1.44$ & $109.93 \pm 0.98$ & $107.50 \pm 1.34$ & $109.25 \pm 0.81$ & 0.023 & 0.756 & 0.780 \\
\hline & MES & $110.33 \pm 1.96$ & $110.31 \pm 1.41$ & $106.00 \pm 1.93$ & $108.98 \pm 0.84$ & & & \\
\hline & Mean & $110.32^{A} \pm 1.04$ & $110.12^{A} \pm 1.00$ & $106.85^{\mathrm{B}} \pm 1.00$ & & & & \\
\hline \multirow{3}{*}{$\mathrm{BL}$ gain } & MS & $7.36 \pm 0.85$ & $3.00 \pm 1.35$ & $9.30 \pm 1.55$ & $6.56^{b} \pm 0.83$ & $<0.001$ & 0.002 & 0.949 \\
\hline & MES & $10.54 \pm 1.55$ & $7.00 \pm 1.57$ & $13.23 \pm 1.67$ & $10.26 a \pm 0.78$ & & & \\
\hline & Mean & $8.91^{A} \pm 0.98$ & $5.00^{\mathrm{B}} \pm 1.07$ & $11.27^{A} \pm 0.90$ & & & & \\
\hline \multirow{3}{*}{ Initial RH } & MS & $126.5 \pm 0.94$ & $136.6 \pm 0.94$ & $128.9 \pm 1.64$ & $130.66 \pm 0.63$ & $<0.001$ & 0.853 & 0.866 \\
\hline & MES & $126.2 \pm 0.86$ & $137.4 \pm 1.39$ & $128.9 \pm 1.25$ & $130.82 \pm 0.66$ & & & \\
\hline & Mean & $126.35^{\mathrm{B}} \pm 0.81$ & $136.97^{A} \pm 0.78$ & $128.89^{\mathrm{B}} \pm 0.78$ & & & & \\
\hline \multirow{3}{*}{$\mathrm{RH}$ gain } & MS & $4.51 \pm 0.52$ & $5.07 \pm 0.62$ & $4.71 \pm 0.71$ & $4.76^{b} \pm 0.33$ & 0.644 & $<0.001$ & 0.273 \\
\hline & MES & $7.66 \pm 0.71$ & $6.46 \pm 0.73$ & $6.38 \pm 0.52$ & $6.83^{a} \pm 0.34$ & & & \\
\hline & Mean & $6.09 \pm 0.42$ & $5.76 \pm 0.40$ & $5.54 \pm 0.40$ & & & & \\
\hline \multirow{3}{*}{ Initial RW } & MS & $37.48 \pm 0.55$ & $37.6 \pm 70.68$ & $36.14 \pm 0.84$ & $37.03 \pm 0.34$ & 0.025 & 0.829 & 0.970 \\
\hline & MES & $37.45 \pm 0.74$ & $37.82 \pm 0.34$ & $36.25 \pm 0.75$ & $37.14 \pm 0.35$ & & & \\
\hline & Mean & $37.40^{A} \pm 0.43$ & $37.71^{A} \pm 0.42$ & $36.15^{\mathrm{B}} \pm 0.42$ & & & & \\
\hline \multirow{3}{*}{ RW gain } & MS & $6.69 \pm 0.41$ & $3.57 \pm 0.44$ & $4.21 \pm 0.55$ & $4.82^{b} \pm 0.22$ & $<0.001$ & 0.017 & 0.884 \\
\hline & MES & $7.25 \pm 0.31$ & $4.38 \pm 0.55$ & $5.15 \pm 0.55$ & $5.60^{a} \pm 0.23$ & & & \\
\hline & Mean & $6.97^{A} \pm 0.28$ & $3.98^{\mathrm{B}} \pm 0.27$ & $4.68^{\mathrm{B}} \pm 0.27$ & & & & \\
\hline
\end{tabular}

BRN= $1 / 2$ Brangus $\times 1 / 2$ Nellore; NEL= Nellore; CAN= $1 / 2$ Canchim $\times 1 / 2$ Nellore; MS= Mineral supplement and MES= Energy mineral supplement. Different uppercase letters, in the same row, and different lowercase letters, in the same column, are significantly different by Tukey's test at the $5 \%$ probability level. P-value: $G G=$ Genetic group; $S=S u p p l e m e n t ; ~ H W=$ height at the withers; $\mathrm{CP}=$ chest perimeter; $\mathrm{BL}=$ Body length; $\mathrm{RH}=$ rump height; $\mathrm{RW}=$ rump width. 
Among the genetic groups, differences $(P<0.05)$ were observed in the initial measurements for $\mathrm{HW}, \mathrm{CP}, \mathrm{BL}, \mathrm{RH}$ and RW. $\mathrm{WH}$ and RW were higher for animals in the NEL group compared to BRN and CAN. According to R. Z. Vaz et al. (2016), the greater rump height of NEL animals is a result of natural selection, as the breed originally from India had to adapt to high temperatures, in which the greater distance between the body and the soil surface results in lower body temperature at the hottest hours or times of the day.

$\mathrm{CP}, \mathrm{BL}$ and $\mathrm{RW}$ were higher for $\mathrm{BRN}$ and NEL compared to CAN, justified by the higher initial weight, even at similar ages. R. Z. Vaz et al. (2016) also observed that the morphometric measurements showed a high correlation with each other and with body weight, indicating that they are good indicators of body development.

There was no interaction ( $P>0.05$ ) between type of supplementand genetic group on the gains of morphometric measurements. Gains of $\mathrm{RH}, \mathrm{HW}, \mathrm{BL}, \mathrm{RW}$ and $\mathrm{CP}$ were higher $(P<0.05)$ for animals that received MES compared to those that received MS. These results were consistent with the work by Rezende et al. (2011), who also observed that crossbred young bulls supplemented with the highest energy level, had greater muscle development, increased chest perimeter and body length. Thus, the supply of MES probably allowed greater availability of net energy for muscle and bone growth in the animals in this treatment compared to animals that received only MS, in addition to favoring the synchrony of ruminal digestion.

There was no difference between genetic groups for $\mathrm{RH}$ gain $(\mathrm{P}=0.644)$. The $\mathrm{HW}$ gain was greater for BRN compared to CAN
$(P=0.019)$, and intermediate for NEL. The gain in $\mathrm{BL}$ was greater for BRN and CAN compared to NEL $(P=0.001)$. The gain of RW was greater for animals in the BRN group compared to NEL and CAN ( $P=0.001)$. The CP gain of the BRN and CAN groups was greater compared to the NEL $(P=0.001)$. With these results, it was possible to prove that crossbred animals have faster growth than purebred animals, and possibly also different body composition gain. In accordance with Menezes et al. (2008), body measurements such as height, body length and chest perimeter are more constant in pure breeds, in line with what was reported for NEL animals in the present study. Furthermore, according to the same authors, in crossbred animals, there are great variations in these measures, mainly due to differences in the genetic composition of the animals.

Serum total protein levels did not differ between treatments $(P>0.05)$ and were close to reference values, ranging from 6.6 to 7.5 $\mathrm{mg} \mathrm{dL}^{-1}$ (Table 6) according to Kaneko, Harvey and Bruss (2008). The decrease in plasma total proteins is related to food deficiency, when pathological causes such as liver failure, kidney and intestinal disorders and hemorrhages are ruled out. It is estimated that diets with less than $10 \%$ protein cause a decrease in protein levels in the blood (Kaneko et al., 2008), therefore, the grass used in the present study was in this lower range of total protein content. The serum albumin concentration also did not differ $(P>0.05)$ depending on the treatments, and was below the normal range for the bovine species in all treatments, which varies between 2.6 and $3.1 \mathrm{mg} \mathrm{dL}-1$, according to $\mathrm{C}$. N. Moreira, Souza, Barini, Araújo and Fioravanti (2012). Blood proteins are mainly synthesized by the liver, and the rate of synthesis is directly related to the amount of dietary 
protein and nutritional status of the animal (González, 2009). These results infer that the performance of the animals was limited by not meeting the protein requirement, this may have affected the maximum microbial growth, which, for animals reared on pasture, with the type of supplement used, microbial protein is the greatest source of metabolizable protein to ruminants (NASEM, 2016).

\section{Table 6}

Mean and standard error of the mean of blood variables of young bulls from three genetic groups, receiving different supplements, on pasture during the rainy season

\begin{tabular}{|c|c|c|c|c|c|c|c|c|}
\hline \multirow{2}{*}{ Variables } & \multirow{2}{*}{ S } & \multicolumn{3}{|c|}{ GG } & \multirow{2}{*}{ Mean } & \multicolumn{3}{|c|}{ P-value } \\
\hline & & BRN & NEL & CAN & & GG & $\mathrm{S}$ & GGxS \\
\hline \multirow{3}{*}{$\begin{array}{l}\text { TP, } \\
\mathrm{mg} \mathrm{dL}^{-1}\end{array}$} & MS & $6.50 \pm 0.18$ & $6.27 \pm 0.41$ & $6.93 \pm 0.35$ & $6.57 \pm 0.23$ & 0.202 & 0.869 & 0.378 \\
\hline & MES & $7.23 \pm 0.25$ & $6.03 \pm 0.75$ & $6.60 \pm 0.34$ & $6.62 \pm 0.23$ & & & \\
\hline & Mean & $6.87 \pm 0.29$ & $6.15 \pm 0.29$ & $6.77 \pm 0.29$ & & & & \\
\hline \multirow{3}{*}{$\begin{array}{l}\text { Alb, } \\
\mathrm{mg} \mathrm{dL}^{-1}\end{array}$} & MS & $1.87 \pm 0.14$ & $1.87 \pm 0.13$ & $2.03 \pm 0.14$ & $1.92 \pm 0.06$ & 0.295 & 0.430 & 0.946 \\
\hline & MES & $1.93 \pm 0.15$ & $1.97 \pm 0.28$ & $2.06 \pm 0.15$ & $1.99 \pm 0.06$ & & & \\
\hline & Mean & $1.90 \pm 0.07$ & $1.92 \pm 0.07$ & $2.05 \pm 0.07$ & & & & \\
\hline \multirow{3}{*}{$\begin{array}{l}\text { Creat, } \\
\mathrm{mg} \mathrm{dL}^{-1}\end{array}$} & MS & $1.77 \pm 0.14$ & $1.53 \pm 0.24$ & $1.70 \pm 0.14$ & $1.67 \pm 0.08$ & 0.057 & 0.143 & 0.427 \\
\hline & MES & $1.87 \pm 0.18$ & $1.57 \pm 0.27$ & $2.07 \pm 0.15$ & $1.83 \pm 0.08$ & & & \\
\hline & Mean & $1.82 \pm 0.09$ & $1.55 \pm 0.09$ & $1.89 \pm 0.09$ & & & & \\
\hline \multirow{3}{*}{$\begin{array}{l}\text { Urea, } \\
\mathrm{mg} \mathrm{dL}^{-1}\end{array}$} & MS & $45.13^{\mathrm{Ba}} \pm 1.45$ & $55.77^{\mathrm{Aa}} \pm 2.35$ & $54.07^{\mathrm{Aa}} \pm 1.45$ & $51.66 \pm 1.37$ & 0.416 & $<0.001$ & 0.012 \\
\hline & MES & $41.30^{\mathrm{Aa}} \pm 2.24$ & $35.27^{\mathrm{Ab}} \pm 2.25$ & $38.67^{\mathrm{Ab}} \pm 2.54$ & $38.41 \pm 1.37$ & & & \\
\hline & Mean & $43.22 \pm 1.68$ & $45.52 \pm 1.68$ & $46.37 \pm 1.68$ & & & & \\
\hline \multirow{3}{*}{$\begin{array}{l}\text { Glu, } \\
\mathrm{mg} \mathrm{dL}^{-1}\end{array}$} & MS & $66.33 \pm 1.97$ & $60.77 \pm 1.34$ & $69.70 \pm 3.44$ & $65.60 \pm 1.11$ & 0.061 & 0.558 & 0.107 \\
\hline & MES & $64.77 \pm 1.25$ & $66.87 \pm 1.37$ & $68.00 \pm 1.34$ & $66.54 \pm 1.11$ & & & \\
\hline & Mean & $65.5 \pm 1.36$ & $63.8 \pm 1.36$ & $68.8 \pm 1.36$ & & & & \\
\hline \multirow{3}{*}{$\begin{array}{l}\text { Chol, } \\
\mathrm{mg} \mathrm{dL}^{-1}\end{array}$} & MS & $97.97 \pm 2.69$ & $83.93 \pm 8.35$ & $88.67 \pm 6.35$ & $90.19 \pm 4.84$ & 0.453 & 0.817 & 0.090 \\
\hline & MES & $76.53 \pm 4.85$ & $93.03 \pm 12.38$ & $105.83 \pm 5.89$ & $91.80 \pm 4.84$ & & & \\
\hline & Mean & $87.25 \pm 5.93$ & $88.48 \pm 5.93$ & $97.25 \pm 5.93$ & & & & \\
\hline \multirow{3}{*}{$\begin{array}{l}\text { AST, } \\
\mathrm{UL}^{-1}\end{array}$} & MS & $86.60 \pm 7.95$ & $102.01 \pm 6.37$ & $86.32 \pm 4.58$ & $91.63^{b} \pm 9.20$ & 0.293 & 0.004 & 0.052 \\
\hline & MES & $141.10 \pm 12.95$ & $97.67 \pm 9.25$ & $135.71 \pm 16.37$ & $137.51^{\mathrm{a}} \pm 9.20$ & & & \\
\hline & Mean & $118.85 \pm 11.27$ & $99.83 \pm 11.27$ & $125.03 \pm 11.27$ & & & & \\
\hline
\end{tabular}

BRN $=1 / 2$ Brangus $\times 1 / 2$ Nellore; NEL= Nellore; CAN= $1 / 2$ Canchim $\times 1 / 2$ Nellore; MS= Mineral supplement and MES = Energy mineral supplement. Different uppercase letters, in the same row, and different lowercase letters, in the same column, are significantly different by Tukey's test at the 5\% probability level. P-value: GG = Genetic group; S = Supplement; TP = total proteins; Alb = albumin; Creat = creatinine; Glu = glucose; Chol = total cholesterol; $A S T$ = aspartate aminotransferase . 
The serum creatinine level did not vary between types of supplements used $(P=$ $0.143)$ and between genetic groups $(P=0.057)$ (Table 6). Creatine is a metabolite used to store energy in muscle, as phosphocreatine, and its degradation to creatinine occurs steadily, around $2 \%$ total creatine daily, and blood creatinine levels are little affected by the diet in ruminants that do not consume food of animal origin, where the reference values are between 1 and $2 \mathrm{mg} \mathrm{dL}^{-1}$ (Kaneko et al., 2008).

There was an interaction $(P=0.012)$ between the type of supplement and genetic group for serum urea levels (Table 6). Animals treated with MS had higher blood urea levels, exceeding the normal reference values, which are between 15 and $40 \mathrm{mg} \mathrm{dL}^{-1}$, according to Corrêa, González and Silva (2010). This can be explained by the imbalance between energy and protein in the diet to maintain ruminal synchronism. According to González (2009), an energy-deficient diet can cause an increase in uremia due to ruminal metabolism, which requires synchrony between the availability of bacterial protein precursors and soluble carbohydrates. According to the same author, with no available carbohydrates, it increases the ruminal ammonia absorption rate, leading to an increase in blood urea, as described above.

Glucose and cholesterol levels were not altered $(P>0.05)$ according to the types of supplements used or between genetic groups (Table 6). Serum glucose levels remained within the range established as normal for the bovine species, ensuring that the animals did not run the risk of going into ketosis (45 to $75 \mathrm{mg} \mathrm{dL}^{-1}$ ) according to Kaneko et al. (2008). Total cholesterol levels were close to the lower interval considered normal, which is $97-145$ $\mathrm{mg} \mathrm{dL}^{-1}$ for adult males (C. N. Moreira et al., 2012).
The serum level of AST was higher in animals receiving MES compared to those that received $M S(P=0.004)$ (Table 6$)$, remaining slightly above the reference values for the species (78 to $132 \mathrm{U} \mathrm{L}^{-1}$ ) (Kaneko et al., 2008). The NEL did not differ between MS and MES. High levels of AST indicate changes in liver tissue, since this enzyme is mainly related to changes in the hepatobiliary system, however, this was not observed in the present study.

\section{Conclusion}

The energy-mineral supplement offered during the rainy period in Tifton 85 pasture is recommended only for Nellore and $1 / 2$ Canchim $\times 1 / 2$ Nellore young bulls, as they had better efficiency in the use of this supplement. For $1 / 2$ Brangus $\times 1 / 2$ Nellore young bulls, the use of a mineral supplement is recommended. Crossbreed animals have greater bodily gains during rearing compared to Nellore young bulls.

\section{Acknowledgements}

This work was supported by COMIGO (Cooperativa Agroindustrial dos Produtores Rurais do Sudoeste Goiano); Instituto Federal Goiano- Campus Rio Verde; Universidade Federal de Goiás and by Capes (Coordination for the Improvement of Higher Education Personnel).

\section{References}

Arnhold, E. (2013). Package in the R environment for analysis of variance and complementary analyses. Brazilian Journal of Veterinary Research and Animal 
Science, 50(6), 488-492. doi: 10.11606/ issn.1678-4456.v50i6p488-492

Association of Official Analytical Chemists (1999). Official methods of analysis of AOAC international( $15 \mathrm{nd}$ ed.). Washington: AOAC.

Barbero, R. P., Malheiros, E. B., Araújo, T. L. R., Nave, R. L. G., Mulliniks, J. T., Berchielli, T. T., \& Reis, R. A. (2015). Combining Marandu grass grazing height and supplementation level to optimize growth and productivity of yearling bulls. Animal Feed Science and Technology, 209, 110-118. doi: 10.1016/j. anifeedsci.2015.09.010

Conselho Nacional de Controle de Experimentação Animal. (2013). Diretriz brasileira para o cuidado e a utilização de animais para fins científicos e didáticos. Resolução Normativa No. 12 de 20 de setembro de 2013. Recuperado de https://pages.cnpem.br/ceua/wp-content/ uploads/sites/56/2015/06/DBCA.pdf

Corrêa, M. N., González, F. H. D., \& Silva, S. C. (2010). Transtornos metabólicos nos animais domésticos. Pelotas: Editora e Gráfica Universitária.

Costa, D. F. A., Silva, S. C. da, Bittar, C. M., Takiya, C., Dórea, J. R. R., Del Valle, T. A., \& Santos, F. A. P. (2019). Citrus pulp-based supplement reduces the detrimental effects of high grazing pressure on the performance of beef cattle under a rotational system of Urochloa brizantha. Revista Brasileira de Saúde e Produção Animal, 20, 1-14. doi: 10.1590/S1519-9940200362019

Cruz, G. M., Rodrigues, A. A., Tullio, R. R., Alencar, M. M., Alleoni, G. F., \& Oliveira, G. P. (2009). Desempenho de bezerros da raça Nelore e cruzados desmamados recebendo concentrado em pastagem adubada de Cynodom dactylon cv. Coastcross. Revista
Brasileira deZootecnia, 38(1), 139-148. doi: 10.1590/S1516-35982009000100018

Detmann, E., Paulino, M. F., Valadares, S. C. Fo., \& Huhtanen, P. (2014). Nutritional aspects applied to grazing cattle in the tropics: a review based on Brazilian results. Semina: Ciências Agrárias, 35(4), 2829-2854. doi:10.5433/1679-03 59.2014v35n4Suplp2829

Dias, D. L. S., Silva, R. R., Silva, F. F., Carvalho, G. G. P., Brandão, R. K. C., Silva, A. L. N., \& Mendes, F. B. L. (2015). Recria de novilhos em pastagem com e sem suplementação proteico/ energética nas águas: consumo, digestibilidade dos nutrientes e desempenho. Semina: Ciências Agrárias, 36(2), 985-998. doi: 10.5433/1679-0359.2015v36n2p985

Freitas, M. D., Neto, Fernandes, J. J. R., Restle, J., Padua, J. T., Rezende, P. L. P., Miotto, F. R. C., \& Moreira, K. K. G. (2014). Desempenho de bovinos machos de origem leiteira submetidos a diferentes estratégias alimentares na recria e terminação. Semina: Ciências Agrárias, 35(4), 2117-2128. doi: 10.5433/1679-03 $59.2014 v 35 n 4 p 2117$

González, F. H. D. (2009). Ferramentas de diagnóstico e monitoramento das doenças metabólicas. Ciência Animal Brasileira, 1(Supl.), 1-22. Recuperado de https://www.revistas.ufg.br/vet/article/ view/7662

Kaneko, J. J., Harvey, J. W., \& Bruss, M. L. (2008). Clinical biochemistry of domestic animals. San Diego: Elsevier.

Kozloski, G. V. (2011). Bioquímica dos ruminantes. Santa Maria: Ed. da UFMS.

Lima, J. B. M. P., Rodríguez, N. M., Martha, G. B., Jr., Guimarães, R., Jr., Vilela, L., Graça, D. S., \& Saliba, E. O. S. (2012). Suplementação de 
novilhos Nelore sob pastejo, no período de transição águas-seca. Arquivo Brasileiro de Medicina Veterinária e Zootecnia, 64(4), 943-952. doi: 10.1590/S0102-09352012 000400022

Martini, A. P. M., Moura, A. F. de, Borchate, D., Adams, S. M., Silva, M. B. da, Cocco, J. M., \& Alves, D. C., Fo. (2020). Comportamento ingestivo e padrões de deslocamento de novilhas de corte em Tifton 85 com diferentes níveis de suplementação. Research, Society and Development, 9 (11), 1-22. doi: 10.33448/rsd-v9i11.10510

Menezes, L. F. G. D., Restle, J., Kuss, F., Brondani, I. L., Alves, D. C., Fo., Catellam, J., \& Osmari, M.P. (2008). Medidas corporais de novilhos das gerações avançadas do cruzamento rotativo entre as raças Charolês e Nelore, terminados em confinamento. Ciência Rural, 38(3), 771-777. doi: 10.1590/S01 03-84 782008000300028

Moreira, C. N., Souza, S. N. D., Barini, A. C., Araújo, E. G. D., \& Fioravanti, M. C. S. (2012). Serum $\mathrm{Y}$-glutamyltransferase activity as an indicator of chronic liver injury in cattle with no clinical signs. Arquivo Brasileiro de Medicina Veterinária e Zootecnia 64(6), 1403-1410. doi: 10.1590/S0102-09 352012000600001

Moreira, F. S., Oliveira, M. M. N. F., Villela, S. D. J., Barbosa, F. A., Mourthé, M. H. F., \& Diniz, F. B. (2015). Desempenho produtivo e econômico de três grupos genéticos de bovinos recriados a pasto com suplementação e terminados em confinamento. Arquivo Brasileiro de Medicina Veterinária e Zootecnia, 67(1), 140-148. doi: 10.1590/1678-7250

National Academies of Sciences, Engineering, and Medicine (2016). Nutrient requirements of beef cattle. Washington, DC: The National Academies Press.
Paris, W., Marchesan, R., Prohmann, P. E. F., Menezes, L. F, G., Zanotti, J., \& Hartmann, D. V. (2013). Utilização de ureia de liberação lenta em sal mineral na suplementação de bovinos de corte em pastagem de Tifton-85. Semina: Ciências Agrárias, 34(1), 409-418. doi: 10.5433/1679-0359.2013v34n1p409

Putrino, S. M., Leme, P. R., Silva, S. D. L., Alleoni, G. F., Lanna, D.P.D., Lima, C. G.D., \& Grossklaus, C. (2006). Exigências líquidas de proteína e energia para ganho de peso de tourinhos Brangus e Nelore alimentados com dietas contendo diferentes proporções de concentrado. Revista Brasileira de Zootecnia, 35(1), 292-300. doi: 10.1590/ S1516-35982006000100037

Rezende, P. L. P., Restle, J., Fernades, J. J. R., Pádua, J. T., Freitas, M. D. F. de, Neto, \& Rocha, F. M. (2011). Performance and body development crossbred dairy cattle submitted to levels of supplementation in Brachiaria brizantha. Ciência Rural, 41(8), 1453-1458. doi: 10.1590/S010384782011005000097

Roth, M. T. P., Fernandes, R. M., Custódio, L., Moretti, M. H., Oliveira, I. M., Prados, L. F., \& Resende, F. D. de. (2019). Effect of supplementation level on performance of growing Nelloreanditsinfluence on pasture characteristics in different seasons. Italian Journal of Animal Science, 18(1), 215-225. doi: 10.1080/1828051X.2018.1504633

Valente, E. E. L., Paulino, M. F., Detmann, E., Valadares Filho, S. C., Barros, L. V., Cabral, C. H. A., \& Souza Duarte, M. (2012). Strategies of supplementation of female suckling calves and nutrition parameters of beef cows on tropical pasture. Tropical Animal Health and Production, 44(7), 1803-1811. doi: 10.1007/s11250-0120142-0 
Van Soest, P. J., Robertson, J. B., \& Lewis, B. A. (1991). Methods for dietary fiber, neutral detergent fiber non-starch polysaccharides in relation to animal nutrition. Journal of Dairy Science, 74(10), 3583-3597. doi: 10.3168/jds.S0022-0302 (91)78551-2

Vaz, F. N., Restle, J., Vaz, R. Z., Brondani, I. L., Bernardes, R. A. C., \& Faturi, C. (2002). Efeitos de Raça e Heterose na Composição física da carcaça e na qualidade da carne de novilhos da primeira geração de cruzamento entre Charolês e Nelore. Revista brasileira de Zootecnia, 31(1), 376-386. doi: 10.1590/ S1516-35982002000200012
Vaz, R. Z., Restle, J., Pacheco, P. S., Vaz, F. N., Muehlmann, L. D., Alves, D. C., Fo., \& Vaz, M. B. (2016). Genetic group and heterosis on morphometric measurements during the growth of male beef cattle. Semina: Ciências Agrárias, 37(4), 2759-2772. doi: 10.5433/1679-0359.2016v37n4Supl1 p2759

Ziemniczak, H. M., Fabian, G. A., Matos, I. J. R., Pazdiora, B. R. C. N., Valentim, J. K., Marques, O. F. C., \& Pazdiora, R. D. (2020). Termination of nelore cattle with different pasture supplementations. Research, Society and Development, 9(4), e131942967-e131942967. doi: 10.3344 8/rsd-v9i4.2967 
